\title{
IAMJ
}

INTERNATIONAL

AYURVEDIC

MEDICAL JOURNAL

\section{STANDARD OPERATIVE PROCEDURE FOR FRORMULATION OF MORINDA CITRI- FOLIA L. GRANULES}

\author{
Krithika R Aithal ${ }^{1}$, Sumanth Shenoy $\mathbf{H}^{2}$, Subrahmanya Padyanna ${ }^{3}$
}

${ }^{1}$ IV Year BAMS, Alva's Ayurveda Medical College, Moodubidire, Karnataka, India

${ }^{2}$ Assosciate Professor, Dept. of Agadatantra, Alva's Ayurveda Medical College Moodubidire, Karnataka, India ${ }^{3}$ Director, Alvas Traditional Medicine Archive (ATMA) and Research Centre, Moodubidire,

Karnataka, India

Email: krithikaraithal@gmail.com

\section{https://doi.org/ $10.46607 /$ iamjp04042020}

(Published online: May 2020)

Open Access

(C) International Ayurvedic Medical Journal, India 2020

Article Received: 27/03/2020 - Peer Reviewed: 07/05/2020 - Accepted for Publication: 23/05/2020

Check for updates

\begin{abstract}
The science of life is the basic meaning of Ayurveda. As like any other medical system, success of treatment also depends upon quality of medicine prescribed to the patient. Standardization of Ayurvedic drugs at various levels starting from the selection and collection of raw materials till the final product. It is essential to produce a safe and efficacious formulation for the needy patients. Preparation of granules is one of modified form of Ghana (solid preparation of herbal extract) and Khanda Kalpana (Solid preparation similar to granules). Present study has elaborated formulation of noni granules with analytical studies conducted as mentioned in Ayurvedic Pharmacopia of India. Noni is the common name of the drug Morinda citrifolia L. and is also called as Indian mulberry. It has been used widely as a complementary and alternative therapy owing to its potent antioxidant property and proven health benefits. As every part of noni plant is useful, it is widely used as Antioxidant, Immunostimulant, Immunomodulant, Analgesic, Antiarthritic, Antipyretic, Antirheumatic, Antitumours, Antispasmodic, Depurative, Diuretic, Antiemetic, Hypotensive, Fungiscide, Laxative, Litholytic, Sedative, Stomachic. The aim of the study is to form noni granules from noni fruit juice by adding adjuvants in order to improve its palatability and shelf life. The prepared granules have shown good palatability and increased shelf life.
\end{abstract}

Keywords: Noni, Morinda Citrifolia L., Ayurveda, Standardization, Granules 


\section{INTRODUCTION}

Nature possess immensely valuable and powerful medicines in the form of plants, minerals etc. Morinda citrifolia $L$. is one such plant commonly known as 'Noni' or 'Indian mulberry' ${ }^{1}$. It belongs to the family Rubiaceae. A small evergreen tree 3-10 m in height; bright green and elliptical leaves, white tubular flowers and ovoid 'grenade' like yellowish white fleshy fruit $5-10 \mathrm{~cm}$ long has a lumpy surface covered by polygonal shaped section, triangular and reddish brown seeds and fruit has a foul taste and odour. Morinda species has been mentioned in our classical texts under Phalavarga in the name of Ashyuka, Akshikiphalaetc ${ }^{2}$. Noni fruits are used by people in different regions for medicinal, commercial as well as a part of food. ${ }^{3}$ Noni is usually recommended in the form of fresh juice and advised to consume immediately ${ }^{4}$ or as a fermented drink which has poor palatability due to pungent taste and odour. Hence present study was planned to change conventional form of noni juice to granules with addition of adjuvant. Avaleha and Khanda Kalpanas are dealt under the preview of Ghana Kriya where the semisolid to solid form of dosage have been described. Conversion of dosage form into more suitable form is essential for modern era with additional benefits of palatability and presentation is always essential.

\section{Materials and Methods: Preparation of Noni Granules}

Raw materials were collected and authenticated by the Botanist. The ingredients used for the preparation of granules are as mentioned in the table no. 1 .

Table 1.

\begin{tabular}{|l|l|l|}
\hline Sl. No. & Ingredients & Quantity \\
\hline 1. & Noni fruits (Morindacitrifolia) & $350 \mathrm{~g}$ \\
\hline 2. & Water & $150 \mathrm{~g}$ \\
\hline 3. & Sita $($ Sugarcandy powder) & $1 \mathrm{~kg}$ \\
\hline 4. & Twak $($ Cinnamomumverum $)$ & $5 \mathrm{~g}$ \\
\hline 5. & Patra $($ Cinnamomumtamala $)$ & $5 \mathrm{~g}$ \\
\hline 6. & Ela (Elatteriacardamomum) & $5 \mathrm{~g}$ \\
\hline 7. & Nagakesara $($ Mesuaferrea $)$ & $5 \mathrm{~g}$ \\
\hline
\end{tabular}

Preparation of Noni granules was carried out at Bhaishajya Kalpana Lab., Alva's Ayurveda Medical College, Moodubidire. General method of preparation emphasized for Khanda Paka is followed in the preparation of Noni Granules ${ }^{5}$. Ripe Noni fruits are taken in the mixer and grinded with sufficient amount of water, the seeds are separated with a help of cotton cloth. 2 parts of sugar candy powder was added to Noni juice and was heated on mild intensity of fire (Mandagni) i.e., $90^{\circ} \mathrm{C}-100^{\circ} \mathrm{C}$ till it attained more than two thread consistency. At this stage, the contents removed from the heat source. Obtained product was added with powdered Twak, Patra, Ela, Nagakesara and mixed rapidly. Then the mixture was dried in hot air oven for $2 \mathrm{hrs}$. Thus formed granules were sieved for equal size of particle. Granules obtained were stored in the airtight container.

Pharmaceutico-Analytical Study: Pharmaceutico-analytical study was carried to establish the basic standards for Noni granules. The studies were conducted in the analytical lab of Dravya Guna Department, Alva's Ayurveda Medical College, Moodubidire and Nitte Pharmacy College as per API Standards ${ }^{6}$.

Under the light of 'Rasa Panchaka', The textbook of Ayurvedic Principles of Drug Action, an independent palatability test ${ }^{7}$ was designed to test the palatability of Noni juice vs noni granules.

100 healthy volunteers were selected, $10 \mathrm{ml}$ of noni juice was served to observe the response regarding palatability (taste), smell and other findings (if any) and instructed to wash the oral cavity (repeated for three times). 
Volunteers were asked to wash the oral cavity with normal water, then $10 \mathrm{ml}$ of noni juice was administered orally and the observations were noted on a questionnaire method. Same procedure was repeated with noni granules $(1 \mathrm{tsp}=5 \mathrm{~g})$ and results were documented.

\section{Observations and Results \\ Preparation of Noni Granules}

After adding sita to the noni juice, effervescence was observed which subsided on constant stirring and heating. Gradual thickening of the syrup, consistency of Tantumatatva (thread like), Darvi Pralepa (adhesion of syrup to spoon) was observed in $45 \mathrm{~min}$ of heating. After $1 \mathrm{hr} 15 \mathrm{~min}$ of heating, the juice was found to have two thread consistency with Apsumajjana (dipping in water). Bindupaka (settled drop of juice in water) with Patitastu Na Shiryate (no instant dissolution in water) was observed at $1 \mathrm{hr} 45 \mathrm{~min}$.Final yield of Noni granules obtained was $1.150 \mathrm{~kg}$. Granules had overcome the disadvantages of noni juice i.e. poor palatability and foul smell. Noni juice was successfully standardized into different dosage form i.e. Noni granules. The details are as mentioned in the table no. 2 .

Table 2:

\begin{tabular}{|l|l|}
\hline Duration & Observations on heating \\
\hline $45 \mathrm{~min}$ & Tantumatatva (thread like), Darvi Pralepa (adhesion of syrup to spoon) \\
\hline $75 \mathrm{~min}$ & 2 thread consistency, Apsumajjana (dipping in water) \\
\hline $105 \mathrm{~min}$ & Bindupaka (settled drop of juice in water), Patitastunashiryate (no instant dissolution in water) \\
\hline
\end{tabular}

\section{Pharmaceutico-Analytical Study}

Table 3: Orgaoleptic character of the Noni Juice and Noni Granules were documented as mentioned in the table no. 3

\begin{tabular}{|l|l|l|l|l|}
\hline Noni juice & \multicolumn{2}{|l|}{ Noni granules } & $100 \%$ \\
\hline Colour & Dark Green & $100 \%$ & Brown & $100 \%$ \\
\hline Appearance & Juicy & $100 \%$ & Granule (Coarse Powder) & $100 \%$ \\
\hline Smell & Unpleasant & $100 \%$ & Pleasant/aromatic & $0 \%$ \\
\hline & Nauseating & $86 \%$ & Unpleasant & $63 \%$ \\
\hline Taste & Extremely bitter & $86 \%$ & Sweet & $37 \%$ \\
\hline & Bitter & $14 \%$ & Sweet with tinge of bitter taste & $0 \%$ \\
\hline Palatability & Non palatable & $89 \%$ & Non palatable & $0 \%$ \\
\hline & Palatable with difficulty & $8 \%$ & Palatable with difficulty & $100 \%$ \\
\hline & Palatable & $3 \%$ & Palatable & $0 \%$ \\
\hline
\end{tabular}

Table 4: The results of analytical studies conducted for the Noni granules are as mentioned in the table no.4

\begin{tabular}{|l|l|l|}
\hline Sl. No. & Analytical Study & Results \\
\hline 1. & Bulk density & $0.56 \mathrm{~g} / \mathrm{cc}$ \\
\hline 2. & Tap density & $0.68 \mathrm{~g} / \mathrm{cc}$ \\
\hline 3. & Compressibility & $17.5 \%$ \\
\hline 4. & Flow property & 26 \\
\hline
\end{tabular}

\section{DISCUSSION}

Noni has been used widely as a complementary and alternative therapy owing to its potent antioxidant property, immunological effect and proven health benefits $^{8}$, but, it cannot by many due to its non-palatability. Hence an attempt is made to bring new 
formulation into stream of science to aid in health benefits of noni fruit juice and also to study SOP (Standard Operative Procedure) of the pharmaceutical preparation of Noni granulation. The organoleptic character indicating brown colour and aroma is due to presence of adjuvant like Twak, Patra, Ela, Nagakesara. Sweet taste is due to addition of sweetening agent Sita and bitter taste is due to noni fruit juice. Palatability test conducted among 100 volunteers proved that the noni granules has more palatability, less irritability and good aroma than noni fruit juice. The analytical studies undertaken showed the results of bulk density, tap density. compressibility, flow property which were observed to be within the limits of permissible values as per Ayurvedic Formulary of India standards which indicates that it has function of structural support and the fine particle size shows that it has more solubility and thus more will be the gastrointestinal absorption.

\section{CONCLUSION}

The Noni granules have shown better palatability owing to its juice. Thus, present study is beneficial to the mass of people. Granule formulation from noni fruit juice helps in increasing the shelf life upto 4 months and also increases the palatability. Thus, one can expect great scope for Noni (Morinda citrifiolia L) Granules. These preparations can be utilized for clinical trial and can be recommended for wider therapeutic as well as nutritional use in future

\section{REFERENCES}

1. https://www.drugs.com/npc/noni.html

2. Sonipradeep et. Al., Geriatric Healthcare through nutraceuticals of Morinda Citrifolia L. Review. AYUSHDHARA,2014;1(2):33-39

3. Heinicke R. Thexeroninesystem: health promting action of noni and bromelion: Direct source published on 2001

4. Sharangadharasamhita commentary by Dr. Himasagara Chandramurthy $2^{\mathrm{ND}}$ EDITION, Madhyamakhanda, swarasaadikalpaniyaadhyaya, (1:12-5) P.182, Chowkamba Krishnadas Publications

5. Vaidya SS, Dole VA. Bhaishajya Kalpana Pratykshika. Anamol Publication, Pune. Reprint 2004. p.40

6. Anonymous, The Ayurvedic Pharmacopoeia of India, Part I, Vol. V, Government of India, Ministry of AYUSH, 2016.

7. Dr. S CDhyani, Rasa panchaka, Chowkamba Krishnadas Academy, Oriental publisher and distributors.

8. Soni Pradeep et. al., Geriatric Healthcare through neutraceuticals of Morinda Citrifolia L. Review. AYUSHDHARA, 2014;1(2):33-39

Source of Support: Nil

\section{Conflict of Interest: None Declared}

How to cite this URL: Krithika $\mathrm{R}$ Aithal et al: Standard Operative Procedure For Frormulation Of Morinda Citrifolia L. Granules. International Ayurvedic Medical Journal \{online\} 2020 \{cited May, 2020\} Available from: http://www.iamj.in/posts/images/upload/2289 2292.pdf 